\title{
第45回 ISO/TC45国際会議に出席して
}

\section{三 橋 健 八*}

\section{1. は じめに}

第 45 回 ISO/TC 45 (ゴムおよびゴム製品の ISO 規格を審議する Technical Committee)の国 際会議に出席したので報告する。今回は 3 回目の 参加であり，更に，今年 5 月よりゴム製品以外に 関する 7 分科会のP メンバーになったことから, 12 名ものメンバーが出席し, 日本としては, 記 念すべき回となった。

会議はマレーシアのペナン島にて, 森林火災に よるへイズが心配されたが，予定どうり 10 月 12 日〜17 日の 6 日間開催され, 日本からは下記の 万ふが出席した。

奥山 通夫 (ブリヂストン), 三橋 健八 (横浜 ゴム), 鳥居 信吾 (日本合成ゴム), 和田 法明 (バンドー化学), 大武 義人(化学品検查協会), 中山 大三 (東海ゴム工業), 安藤 巽 (元・鬼怒川 ゴム工業), 沢田 宏之(日本ゼオン), 川中 孝 文 (日本ゼオン), 村上直毅 (日本合成ゴム), 新 海 正浩 (日合商事), 佐藤 親弘(上島製作所)

今回より, 日本は全体会議である Leaders 会 議やPlenary 会議への参加が義務付けられ, 正

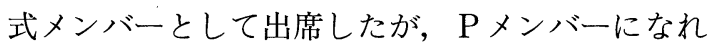
なかったゴム製品に関する会議 (ゴムホース, ゴ ム引布, ゴム板, スポンジゴム等)でも日本の席 が用意され，特に， 71 件もの規格数を有するゴ ムホース分科会への出席を要請され, 奥山委員長 に一部参加していただいた。

参加国は TC 45 全体の P メンバー 27 か国中, 12 か国の参加で, 合計 107 名の参加者があった.

* 横浜ゴム侏) タイヤ材料設計部

(干254 神奈川県平塚市追分 2-1)
参加人数を次に示す.

アメリカ 20 名, イギリス 16 名, マレーシア 16 名, 日本 12 名, 夕イランド 7 名, スウェーデ ン 7 名, フランス 6 名, カナダ 5 名, イタリー 4 名, ドイツ 4 名, インドネシア 4 名, オランダ 1 名，事務局 5 名であった。

会議内容の報告に入る前に，今回特別に ISO 中央事務局より指導を受けた“Training and information programme”について報告する.

指導内容の趣旨は, 提案された規格案をいかに 早く ISO 規格に作り上げるか…… の説明で あった. WD〜ISO までの期間を 5 年から 3 年以 内に短縮する。そのためのチェックポイントとし て, そのISO は本当に必要か? その ISO は今 後増加して行く内容か? 規格の内容はコマーシ ヤル過ぎないか？ 質は良いか？ 手続きは正し いか？FDIS 発行後にフランス語のバージョン を発行しているか？等の説明があった.

更に, 近い将来 ISO 規格の送付, 規格に関す るコメント回答，NWP 等はすべて CPUによる E-mailにより行われ, 各国事務局およびエキス パートの E-mail 番号の登録が義務付けられる。 E-mail はすべてWindows 95 Microsoft Word 6.0 を基準として通信を行う. ISO 規格の書き方 に関する CPUソフトを後ほど ISO 中央事務局よ り配布し, 徹底をはかる。この方法は, ISOす べてのTC(約 200 の Committee)に対して行な われ，約 1 万件の ISO 規格に対して適用される. ……等を 2 日間にわたって教育を受けた。

我々もこの E-mail 化に対して，まずゴム工業 会の事務局から準備を進めなくてはならないと, 考えている. 


\section{2. 会 議 内 容}

会議には連日手分けして可能な限り出席し, 日 本の意見を述べてきた。各会議の討議内容は例年 と変わりなく, ISO/DIS, CD 規格への各国回答 に対する審議や，NWP に関する討議であった。 各会議参加者の報告を整理し， Pメンバーとして 回答し始めた 5 月以降の案件を中心に報告する.

\subsection{TC 45/WG 1 (Chemical tests)について} 化学分析の主査 Mr. Lussier (米国)により，11 件の ISO 規格案が審議された。

・ISO/DIS 4650 (赤外分光光度計によるゴムの 分析法) FDISになる

・ISO/CD 7270(ガスクロによるポリマーの同 定法) DISになる

・ISO/CD 9924-2(TGAによる極製ゴムの組成 分析法) DIS になる

これは，日本より CRの追加を提案したとこ ろ，CR を用いた TGAのデー夕を，'98 年 2 月 までに提出するよう要請された.

・ISO/WD 11344 (GPCによる分子量および分 布の測定法）…………DIS になる

・ISO/NWP（GPCによるNRの分子量および 分布の新しい測定法)

これは，イタリー，タイ，USA，UKによっ て規格案を作成する

・ ISO/CD 12965 (赤外分光光度計による BR の ミクロ構造の測定法） ‥DIS になる ただし，日本より規格中で規定している二硫化 炭素は健康上問題があるので MEK への変更を提 案したところ，MEKを使用したデー夕を，'98 年 2 月までに提出するよう要請された。

・ ISO/CD 14558(赤外によるHNBRの不飽和 二重結合量の測定法） $\cdots$ DIS になる

・ ISO/NWP よう素滴定法 HNBR の不飽和二 重結合量の測定法

これは日本提案であり,' 98 年 2 月までに原案 と精度デー夕を提出する.

・ ISO/CD 15671(Sulfur の自動分析法)

DIS になる

ただし, 日本提案により自動分析器の表現を商 品名から一般表現に変える.

・ISO/CD 15672 (Nitrogenの自動分析法) DIS になる

- ISO/1407 （溶剂抽出分の測定法）
5 年ごとの見直しに入る

\subsection{TC 45/WG 10(Terminology)について}

ゴム用語の主査 Mr. Duda (米国)により 4 件の ISO 規格案が審議された。ゴム用語の規格 ISO 1382 は昨年改正されたばかりで, 今年は Amendmentについてのみ審議された。

- ISO 1382/DAM 1, DAM 2, DAM 3, (ゴ 厶用語) …………3 単語が追加……AM になる

・ISO 6472/DAM 2 (ゴム用配合剂の略号)

DDAM 2.2 になる

ただし，反対意見が多く，Mr. Price(英国)に より再編集される。

・ISO/NWP （コンピュータによるゴム Compound の分類法)

これは, ASTM 5899 により米国より提案され る予定

2.3 SC 2/WG 1(Physical and visco-elastic properties)について

物理試験関係の主查 Mr. Brown(英国)により 20 件の ISO 規格案が審議された。

- ISO/DIS 4664 (加硫ゴムの動的性質測定方法の ガイド） ………………..........FDIS になる

ただし，日本が曲げ(bending)とねじり(torsion) 項の editorial ミスを指摘

- ISO/NWP (加硫ゴムの動的性質測定方法)

これは, 日本提案であり, DIS 4664 がガイド

であるため, 試験方法を規定する原案と精度デー 夕を’98 年 2 月までに提出する。これにより，本 年度改正審議を行った JIS K 6394 の内容が ISO 規格案として提案される.

・ISO/DIS 6502(キュアメータによる加硫特性の 測定方法のガイド）…………2nd DIS になる これは, 日本より，ローターレスキュアメータ として, JIS K 6300「未加硫ゴムの試験方法」で 規定している FPD (Flat-plate die) タイプについ て精度面での優位性を強調し, ISO 規格案への 追加を提案した. 測定精度の比較案ITP (Interlaboratory Test Program)を米国が作成 し，日・米間で実施する。

・ISO/DIS 2285(常温における引張永久ひずみ測 定方法)

・ISO/DIS 12244 (一定荷重下における・伸び，ク リープ，および永久伸び試験方法)

ただし，上記二つの規格案は結合され，New Work Item として Mr. Hall(英国)が中心になっ 
て作成する.

・ISO/CD 36 (加硫ゴム一織布の接着強さ測定方 法) DIS になる

・ISO/CD 3384 (常温と高温での圧縮応力緩和測 定方法) DDISになる

ただし，日本は大型試験片(低硬度ゴムの測定 用として)の規定を要望したが，既に相関データ をとっているので却下された。また Mr. Spetz (スウェーデン)より新しい ITP プログラムが提 案された。 日本も参画するか否かは, 後日回答す

る.

・ISO/NWP 289-3(油展 SBR のデルタムーニー 值の測定方法) DIS になる ただし，日本，カナダからの意見で油展 SBR に限定しない。

・ISO/DIS 6179 (揮発性液体の蒸気透過速度の測 定方法) FDISになる ただし，日本提案の防爆装置は安全性の観点か ら FDIS で審議.

・ISO 48(加硫ゴムの IRHD 硬さ測定方法) ·数式を修正し, Amendment になる

- ISO 2878 (導電性又は静電防止性材質一電気抵 抗測定法),

・ISO 3383(ゴムを標準温度以外で試験する場合 の一般指針),

・ISO 4661-2(試験片又は試験試料の調整) 上記 3 件の規格は 5 年ごとの定期見直しを完了 した.

•ISO/DIS 1853 (導電性, 静電性ゴムの電気抵抗 測定法) FDIS になる ・ ISO/DIS 6133(多数のピークを持つ曲線の解析 方法) FDIS になる

・ISO/FDIS 2921 (加硫ゴムの定温 TR 試験), .ISO 発行へ

・ ISO/FDIS 6505(加硫ゴム一金属との粘着およ び腐食の測定方法), ISO 発行へ

・ISO/FDIS 7267-1 (ゴム被覆ローラーIRHD 見

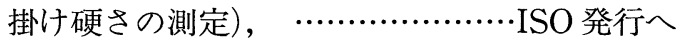
・ISO/FDIS 7619 (ポケット硬さ計による貫入硬 さの測定方法), ISO 発行へ

・ISO/FDIS 11345 (ゴム中のカーボンブラック分 散の迅速測定法) ISO 発行へ

\subsection{SC 2/WG 3 (Degradation tests)について} 劣化試験の主查代理として Mr. Spetz(スウェ ーデン)により， 7 件の ISO 規格案が審議され
た。なお，WG 3 の主査は来年から Mr. Heinz (独)が就任する.

・ISO/DIS 4665(加硫ゴムの耐候性試験) FDIS になる

ただし，日本で主に使用されているオープンフ レーム(サンシャイン)カーボンアークランプによ る方法が日本以外では使用されていない理由で規 定されておらず，入れてもらうよう要望した。そ の結果，本文中の NOTEとして付記されること となったが, 同時に, 日本としても JISの改正 等を検討するよう発言された。

・ISO/NWP(摩耗試験の指針) ………CD になる ただし，摩耗試験のガイドが Mr. Brownより 提案され，日本もガイド作成に参加する旨申し出 た. 更に，日本の NWP として JIS K 6264 に規 定の改良ランボーン式摩耗試験を今後提案したい 旨提案した。

・ISO/DTR 1431-3 (実験室のオゾン試験機のオ ゾン濃度測定方法) DIS になる

ただし，3 種類の方法が規定されている。その 中で，日本が基本として使用しているクーロメト リ法(湿式化学法)の追加を提案したが，すでに規 定されている他の 2 法との違いを検討したうえで 採否が決定される。

・ISO/DIS 1817 (加硫ゴムの耐液体試験方法) FDIS になる

・ISO/CD 188/DAM 1 (加硫ゴムの促進老化, 耐 熱試験方法の精度検討) FDIS 188 へ移行

ただし，米，スウェーデンからのコメントによ り計算方法を修正，また，空気置換率，風速の影 響などは TC 61(プラスチック)専門委員会へ情報 を提供した。

・ISO/CD 4649.2(ロータリードラムを用いた摩 耗試験方法）………………2nd CD になる ただし，摩耗指数の算出式を統一する。 また， 試験用ゴム材料, 摩耗試験機などの提供者リス卜 はメンテの問題から付属書より削除する.

・ISO 11346(アレニウスプロットを用いた寿命 と最高使用温度の測定）………...ISO として発行

2.5 SC 3/WG 1 (General methods for sampling, mixing and vulcanization)について 原料ゴムの一般に関する主査 Dr.Bowman (英 国)により，定期見直しによる 2 件の ISO 規格案 が審議された。

・ISO 1795(原料ゴムのサンプリングと保存方 
法) DIS になる

ただし，最低サンプリング量を $600 \mathrm{~g}$ から 350 $\mathrm{g}$ に, 低粘度 $\mathrm{EPDM}$ のロール温度を $35 \pm 5{ }^{\circ} \mathrm{C}$ と する。

・ISO/TR 7664 (原料ゴムの貯蔵方法のガイド) DISになる

ただし，貯蔵温度について議論されたが，ガイ ドのため，原案どおりとした。

\subsection{SC 3/WG 2(Latex)について}

ラテックスに関する主查D D.Coe(英国)により 9 件の ISO 規格案が審議された.

・ISO 498 (濃縮天然ゴムラテックス・ドライポリ マーの調製法) ……………....改正 ISO になる ・ISO 506 (濃縮天然ゴムラテックス・揮発性脂肪 酸数測定法) ………………...改正 ISO になる ・ISO 1802 (濃縮天然ゴムラテックス・嗍酸量測 定法) ………………………改正 ISO になる ・ISO 2005 (濃縮天然ゴムラテックス・スラッジ 量測定法) ……………………改正 ISO になる ・ISO 2008(SBR ラテックス・揮発分と残留スチ レン量測定法)……廃止する

上記 5 件の規格は 5 年ごとの定期見直しを完了 した.

・ISO/CD 12243・2(天然ゴムラテックス製手袋に 含まれる溶出たんぱく質の定量） $\cdots 3$ rd CDに ただし，この規格案に対してASTM法，CEN 法, マレーシア法の欧, 米, 東南アジアの激しい 議論が 2 時間に及んだ。米国はFDA 規定のべー スになるASTM 法を主張し，マレーシアは生産 国として自国の方法を主張し，結局，双方の方法 でクロスチェックを行い，来年度討議することに なった。

\subsection{SC 3/WG 3 (Carbon black)について}

カーボンブラックに関する主査 Dr. Dunn(カナ ダ)により8件の ISO 規格案が審議された。

・ISO 1126 (カーボンブラックの加熱減量測定 法) …………………….....改正 ISO になる ・ISO 1437 (カーボンブラックのふるい残分測定 法) ………..........................改正 ISO になる ・ISO 3257(カーボンブラックのSBRにおける 評価法) ……………………改正 ISO になる 上記 3 件の規格は 5 年ごとの定期見直しを行 い，測定精度のデータ付けて完了する。

・ISO/DIS 1304 (カーボンブラックのよう素吸着 量測定法) ·投票中
・ISO/DIS 3858(カーボンブラックのトルエン着 色透過度測定法) 投票中

・ISO/DIS 1125(カーボンブラックの灰分量測定 法）………....................................投票中

・ ISO/CD 4656-1(カーボンブラックの DBP 吸 油量測定法) NWP になる ただし，この規格はISO6894 (圧縮試料のDBP 吸油量測定法) と結合してNWP としてドイツよ り提案される。

・ISO/CD 4656-2(カーボンブラックの DBP 吸 油量・プラストコーダ法）…………来年審議する ・ISO/CD 15825 (遠心分離光学沈降機によるアグ リゲート測定法）……............2nd CD になる ただし，この規格は測定精度のデータが必要。

・ISO/DIS 1304/DAM 1 (よう素吸着量測定法・ 電位差法) …………….....DIS 1304-2 になる ただし，この規格は測定精度のデータが必要.

・ ISO/CD 4652-2/DAM 1 (窒素吸着比表面積・多 点法）…………………CD 4652-2 になる ただし，この規格は多点法およびStatistical Thickness Surface Area 法としてカーボンブラ ックとシリカの両方に適用され ISO 5794-1 と結 合する．同時に，測定法も見直される。

\subsection{SC 3/WG 4(Natural rubber) について} 天然ゴムに関する主査 Mr. Halim(マレーシ ア）により 2 件の ISO 規格案が審議された。

・ISO/DIS 4660 (天然ゴムの色調指数試験) ·投票中

・ISO/CD 2000.3(天然ゴムの格付けに関するガ

イド) .DISになる

ただし，この規格案に対して生産国である夕イ ランドより ORIGIN (原料の形状によりクラス分 けを行う)の項目を規格より削除するよう, 強く 要求し, 米国はガイドだから残すように反論し, 激しい議論になった。結局，出席者による投票を 行い, 夕イランドの要求が通り, ORIGIN の項 目は削除された。

2.9 SC 3/WG 5(Synthetic rubber)について 合成ゴムに関する主查 Mr. Colineau(フラン ス)により 3 件の ISO 規格案が審議された.

・ISO/FDIS 4659 (SBR マスターバッチの評価 法）…………………………….....投票中

・ISO/CD 2303（IR の評価法） ‥2nd CD になる ただし，日本より混合法にインターナル混合法 を追加するよう提案したところ，ロール法，イン 
ターナル法の両方について, 日本 ( 2 か所), イ夕 リー ( 3 か所)，米国 ( 1 か所) で測定精度に関する ITPを行い, ’98 年 2 月〜 5 月の間にデー夕を提 出することになった.

・ISO/CD 4097(EPDM の評価法)……DIS になる ただし，日本より低粘度 EPDM 品を規格に記 載するよう追加要求したところ, 各国より賛同が 得られ，informativeとして受け入れられた。 た，EPDMについても日本 ( 2 か所)，イタリー ( 3 か所), 米国 (1 か所)で測定精度に関する ITP を行い, '98 年 2 月〜 5 月の間にデータを提 出することになった.

\subsection{SC 3/WG 6 (Non-black ingredients) に ついて}

配合剂に関する主査 Dr. Panenka(独)により 6 件の ISO 規格案が審議された。

・ ISO 5794-1/DAM 1 (シリカについて)

……ISO/DIS 4652-2 と結合され CD になる ・ISO 5794-2(シリカ配合レシピと物性測定法)

.FDISになる

・ISO/DIS 11235(スルフェンアミド系加硫促進 剂の試験法) FDIS になる

・ISO/DIS 11236(フェニレンジアミン系老化防 止剂の試験法) FDISになる

ただし，上記 4 件に関して日本の意見を提出し てあったが，意見に対する根拠となるデー夕もな

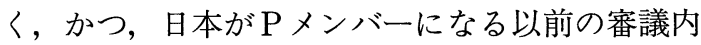
容であり，更に，DISであったところから，全 く取り上げてもらえなかった.

・ISO/NWP(CTABによるシリカの表面積測定 法)

これは，NWP として提案する前に測定精度に 関するITPがドイツにより実施されている.

・ISO/NWP(プロセスオイルについて)

これは, NWPとして提案する前に GC/ MASSによるポリアロマチック炭化水素と DMSO 抽出物の測定精度に関するITP が英国, イタリーにより実施されている.

\subsection{1 全体会議について}

全体のChairmanであるマレーシアのDr. Kadir は実質今年が一年目にあたり，いろいろな 改善が提案され，来年より実施されることとなっ た. 例えば，今まで期間中に 2 回の全体会議 (Leaders 会議)が開催されていたが, これが 1 回 となり，他の 1 回は “Committee Officers Meet- ing” (Chairman 会議)となった。これで期間中 “Planning 会議” と “Chairman 会議” と “Leaders 会議”がそれぞれ 1 回づつ開催される こととなった.

また，TC 45 の組織の見直しも検討され，TC 45 に直接繫がっているWGについて既存の SC に含まれるとか, 新しい SCに分離されるとか, が検討されたが, 当面; 現状の組織で進めること となった。

来年度の ISO 規格の投票期限が決まり, NWP の提案期限, ISO 規格への回答期限が明確にな り，来年度の国際会議に向けてスタートされた。 また, 今後予定されている国際会議の開催国は次 のよjに報告され，日本では 2004 年に開催する ことが決定された。 今後, 日本での開催に向けて 計画的に課題を達成していくことになろう.

1998 年 Thailand, 1999 年 Hungary, 2000 年 Germany, 2001 年—， 2002 年 Italy， 2003 年 United Kingdom, 2004 年 Japan

1998 年の Thailand での国際会議は 11 月 8 日 よりバンコックで開催予定となった。

\section{3.おわりに}

今回, 日本からは次の 4 件の主要提案を行っ た.

(1) ISO/CD 14558 (赤外分光光度計による H.NBR の残留不飽和結合の測定法)によう素化法による 方法を追加する件

(2) ISO/CD 4097(EPDM の試験法)に JIS で規定 する低粘度 EPDM を追加する件

(3) ISO/DIS 6502(キュアーメータによる加硫特 性測定法のガイド)に JIS で規定するローターレ スキュアーメータを追加する件

(4) ISO/DIS 4665(耐候性の測定法)に JIS で規定 するカーボンアーク法を追加する件

これら主要提案はいずれも NWP, CD，又は 備考(informative)として受け入れられたが，別 の提案では，全く受け入れられない項目もあっ た. すなわち, 提案する場合, その提案内容の根 拠, 例えば, デー夕等を示し, 現行 ISO とのデ 一夕差および提案内容の測定精度等を提示しなく てはならないと，指導を受けた。もちろん，口ジ カルな根拠があれば, いつでも提案して欲しい。 5 年間(改正時期まで)待つ必要はない. Amendment (修正)として検討するから……とか, 日本 
として興味のある規格案には, 始めからプロジエ クトメンバーとして参加し，原案に日本の意見を 盛り込むように……か, 種々な提案方法につい て配合剂の主査 Dr. Panenka や化学分析の主査 Mr. Lussierより指導を受けた。 それにしても， NWP 2 件, CD 2 件, 等の提案が出来たのは, 昨年, 一昨年と比較して大きな進展といえよう。

日本から 12 名もの代表者を派遣し，一躍，世 界の第 4 位の規模になってしまった. 今回初めて 参加した日本の代表者達の共通意見として, 世界 の人々の活動状況に触れ, 日本が今，何をすべき かが分かったこと，何か貢献して始めて意見を聞 いてもらえること，等多くの体験をすることがで き, 今後の活動に結び付けることができると感謝 している。一方，世界の人々は喜んで日本を受け 入れると同時に日本に対し警戒感を持ったにちが いない。これからは，日本を ISO/TC 45 に関す る一人前の国として対応して来ると思われる。そ れに対して, 我々は, 彼らの期待を裏切らないよ う，あくまでもデータをべースにロジカルに，語 学のハンデイを乗り越えて, 世界の人々とコミュ

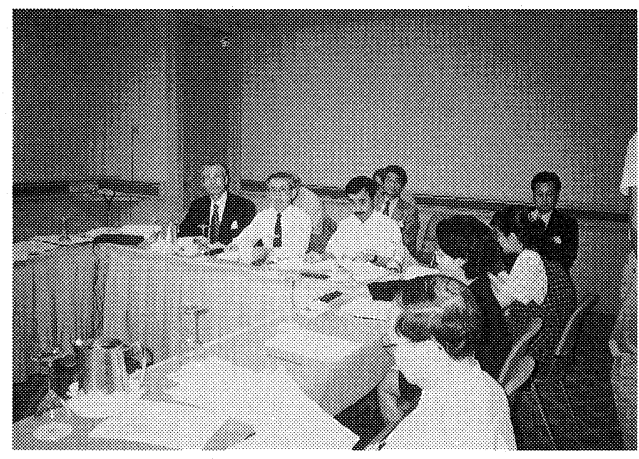

写真 1 SC $2 / W G 1$ の会議中
ニケーションし, 互いに助け合い, 理解しあいな がら前に進むことが大切と考える.

最後に, 今回の会議に出席するに際し, 多大な 協力をいただいた通商産業省工業技術院，日本規 格協会, 日本ゴム工業会, および関連各会社の 方々に深く感謝いたします。

また，本文中，

(1) TC 45/WG 1 (Chemical tests)については大武 巳ん(化学品検查協会),

(2) SC $2 / \mathrm{WG} 1$ (Physical and visco-elastic properties)およびSC 2/WG 3(Degradation tests)に ついては和田さん(バンドー化学),

(3) SC $3 /$ WG 1 (General methods for sampling, mixing and vulcanization), SC $3 / \mathrm{WG} 2$ (Latex), SC 3/WG 3(Carbon black), SC 3/ WG 4(Natural rubber), SC 3/WG 5

(Synthtic rubber), SC 3/WG 6(Non-black ingredients)については鳥居さん(日本合成ゴム), 中 山さん(東海ゴム工業)に記述していただきまし た。

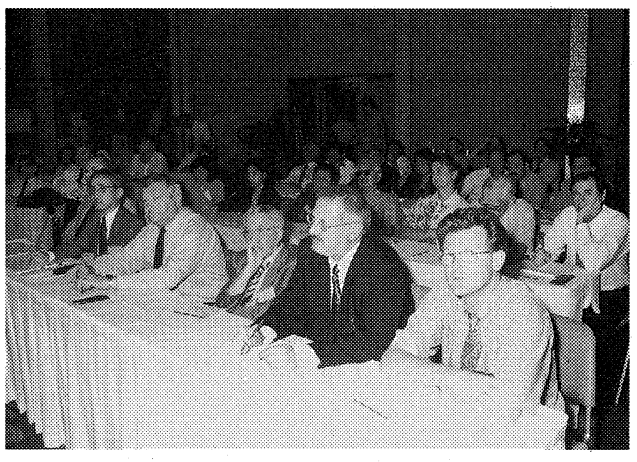

写真 2 Training プログラムに参加

* 